\title{
Therapeutic education process at An Islamic Hospital in South Kalimantan, Indonesia
}

\author{
Taufik Hidayat ${ }^{1}$, Mahyuddin Barni ${ }^{2}$, Agus Setiawan ${ }^{3}$ \\ ${ }^{1}$ Islamic Counseling Guidance Study Program, Faculty of Da'wah and Communication Studies, Antasari State Islamic University, \\ Banjarmasin, Indonesia \\ ${ }^{2}$ Islamic Education Study Program, Postgraduate Faculty, Antasari State Islamic University, Banjarmasin, Indonesia \\ ${ }^{3}$ Islamic Education Study Program, Faculty of Tarbiyah and Teacher Training, Sultan Aji Muhammad Idris State Islamic University,
} Samarinda, Indonesia

\begin{tabular}{l} 
Article Info \\
\hline Article history: \\
Received Dec 15, 2020 \\
Revised Nov 22, 2021 \\
Accepted Dec 2, 2021 \\
\hline
\end{tabular}

Keywords:

Health workers

Interpersonal competence

Islamic hospital

Motivation

Perception of healing

\begin{abstract}
This study aimed to determine the effect of Islamic interpersonal competence integrity as a therapeutic education process on healing motivation. Researchers used Sequential Explanatory Designs as a research design. The respondets were Muslim patients who received inpatient services at the Banjarmasin Islamic Hospital. Subjects were 147 patients who were taken sequentially using a consecutive sampling technique. Researchers used Chi-square inferential statistical tests and Logistic Regression tests in quantitative analysis, while in qualitative analysis, researchers used Taxonomic analysis. The results of the Chi-square analysis showed that there is a significant relationship between each aspect of Al-Luthfu (hospitality), Al-Adab (politeness), Al-'Uthfu (gentleness in the form of attention), and As-Shabru (patience) with healing motivation. The results of the Logistics Regression analysis showed that simultaneously there was a significant effect on aspects of Al-Luthfu, Al-'Uthfu, and As-Shabru on healing motivation. Qualitatively, the process of implementing Islamic interpersonal competence integrity education considers the patient's level of anxiety, stress level of chronic illness and avoids patient discomfort to nurses. This study suggested to nurses of Banjarmasin Islamic Hospital to build a commitment to serve patients by prioritizing aspects of As-Shabru, building Islamic-based communication, increasing educational competence, and understanding patient characteristics.
\end{abstract}

This is an open access article under the $\underline{C C B Y-S A}$ license.



\section{Corresponding Author:}

Agus Setiawan

Faculty of Tarbiyah and Teacher Training, State Islamic Institute of Samarinda

Street H. A. M. Rifaddin, Harapan Baru, Loa Janan Ilir, Samarinda City, Indonesia

Email: agus.setiawan@iain-samarinda.ac.id

\section{INTRODUCTION}

Why do some sick people get well without medicine and others cannot? This research departs from this question. Many perspectives explain the basis of the concept of health and illness in humans, ranging from preventive, curative and rehabilitative studies, all of which are discussed in various approaches such as medicine [1], psychology [2], epidemiology [3], service quality [4], to the concept of customer satisfaction [5]. How about Islam? The Islamic perspective explains that "being healthy" is part of the greatest blessings of Allah, although basically, health is not necessarily better than being sick because these two cases have the same potential to be labelled good and evil in the sight of Allah [6]. The question is, does this then weaken the concept of healthy? Of course not; this is precisely the focus of Islam. God gives justice that humans are entitled to merit and sin from their health and sickness. What can be done in a state of health is better than what can be done in a state of illness. Humans in good health can be more productive to work, worship and 
preach [7]. Prof. Quraish Shihab argues, "healthy" in Islam essentially describes the functioning of all human physical and spiritual potential so that they can achieve their goals on this earth [8]; thus, a healthy human being is "a human being who is prosperous, physically and spiritually balanced, and beneficial in his presence on an ongoing basis" [9].

As it is known that physical and psychological are one unit [10]. The physical condition affects the psyche and vice versa; the psychic affects the physical state [11]. Cases in the health sector show that people who experience depression significantly affect their sleep patterns, whereas lack of sleep affects a person's mental health [12]. This reciprocal influence shows the existence of a healthy psyche and a psychological disorder in the sick person. This fact is the focus of researchers to explore the influence of emotional and psychological forces in moving individuals to escape from defeat against physical pain. Because actually, peace of mind can encourage intrinsic motivation to recover from illness so that individuals only need to get adequate rest and treatment, not merely the result of taking drugs.

Psychologically, the urge to recover from illness is called healing motivation. When the driving force is strong, recovery efforts will be carried out in earnest and directed so that the chances of recovery are more significant. However, when the driving force is weak, recovery efforts are not taken seriously, so that the possibility of recovery tends to be more prolonged or even tricky [13], [14]. Therefore, someone who is declared to be suffering from a particular disease if he does not have a strong healing motivation is believed to hinder the healing process [15].

In health services, the picture of the healing motivation of inpatients is an average of $2.36 \%-4 \%$ in terms of aspects of positive attitudes towards illness and aspects of intrinsic motivation [16]. In the aspect of a positive attitude towards illness, the low motivation to recover is indicated by the patient's refusal to receive treatment from health workers; such as refusing to take medicine because there is no change after taking medicine regularly, denying the officer's explanation and wanting to find another expert as a comparison, complaining of pain but not wanting to follow the officer's instructions, refusing to maintain eating and sleeping patterns. Meanwhile, the intrinsic motivation aspect is indicated by; low hope for recovery does not want to be a burden on the family, resigned to the situation and chose death as the best way. If not handled, the low motivation for healing will increase death in patients [17]. For this reason, the problem of healing motivation requires intervention; Of course, the intervention that can increase knowledge and confidence to recover is the availability of quality health services [18].

In connection with efforts to maintain the quality of health services in hospitals, it is inseparable from the vital role of health workers (nurses). According to Patricia Iyer, in carrying out health services, nurses have three service functions, namely: independent function, dependent function, and cooperating function [19]. Of the three service functions, the independent function has the most challenging task because nurses are tasked with providing calm and comfort in the patient's treatment process. This is where interpersonal competence is needed in overcoming the problem of healing motivation because of the failure to build a therapeutic relationship between nurses and patients [16]. Good interpersonal competence can build a therapeutic relationship. Patients need a sense of security and comfort during the treatment process. This feeling will arise when the patient is accepted for who he is, motivated, respected, and treated in a friendly manner; In addition, nurses are also expected to be able to understand the patient's anxiety, do not differentiate social status, and be responsive to any changes experienced by the patient [20], [21].

Caring for the sick does require extra patience, especially for the elderly; everything can not be separated from the professionalism of nurses in their interpersonal roles. Although the implementation of treatment must be professional, there is something more critical that Islam emphasizes to achieve its goal, namely treatment with "Akhlakul Karimah", this is where the role of integrity is needed. Then, what is integrity? According to the guidance of the Prophet, integrity is the concept of consistency in acting based on values, ethical principles, and loyalty with full awareness and a sense of responsibility in Islam [22]. The lack of integrity in nurses' interpersonal competence only makes interpersonal competence no more than communication skills, with more extreme language such as "role-playing" or "acting". The behaviour that appears is not purely based on good morals and will be finished when the show is over; in such circumstances, nurses will do a mere routine, nothing more than physical activity that results in fatigue.

Referring to the personality of the Prophet, the morals that Muslim nurses must possess are: i) Al-Luthfu (hospitality); a sign of humility and piety. ii) Al-Adab (courtesy); respect for patients based on shame for fear of doing not commendable things, so they try to avoid reproach and humiliation. iii) Al-'Uthfu (tenderness in the form of attention); the virtue of putting the patient's interests first, willing to listen to patient complaints, trying to keep promises and helping with love. iv) As-Shabru (patient); related to the control of lust and the search for meaning or wisdom in every good and bad experience [23]. By applying the integrity of Islamic interpersonal competence, nurses are expected to provide peace and comfort to inpatients.

There is a process of educative interaction in the dynamics of good interpersonal relationships, such as transfer of reference, transfer of knowledge, transfer of motivation, and supportive attention. The 
establishment of educational interactions between nurses and patients can affect the motivation to heal; this is by what is stated in the book "Hospital Accreditation Standards 2012 version" that nurses have a dual role, namely functioning as "therapeutic personnel as well as educators" [24]. This process occurs when the nurse establishes contact with the patient, such as when visiting, examining, caring for, or rehabilitating in preparation for discharge. By using the integrity of Islamic interpersonal competence, educational interactions are carried out with a friendly attitude, courtesy, attention, and patience in the form of advice or information. In addition, nurses also act as facilitators in establishing a conducive environment to motivate patients to follow their directions properly. This situation is referred to as the therapeutic education process, which starts from the pre-interaction phase (data collection and planning), the orientation phase (conducting cognitive, psychomotor, and affective validation), the work phase (doing therapy, care, and medication), and the termination phase (discontinuation or follow-up process) [25]. This therapeutic education is provided to help patients better participate in treatment and make decisions about their care [26].

Based on the background above, this discussion is helpful for researchers to understand the facts related to Ukhuwah Islamiyah, healing motivation, therapeutic education and health services with Islamic integrity at the Banjarmasin Islamic Hospital. The main objective of this study was to "know the effect of the integrity of Islamic interpersonal competence as a therapeutic education process with healing motivation in patients at Banjarmasin General Hospital". Then specifically, namely: i) To determine the patient's characteristics (including gender, age, and education), ii) To determine the frequency distribution of the patient's healing motivation, iii) To determine the patient's perception of the integrity of Islamic interpersonal competence in nurses, iv) To determine the partial relationship of each aspect of the integrity of Islamic interpersonal competence (Al-Luthfu, Al-Adab, Al-'Uthfu and As-Shabru) on the motivation of healing patients, and v) To know the process of therapeutic education during patient care and its obstacles.

\section{RESEARCH METHOD}

This type of research is non-experimental research which is classified as Field Research, while the research design uses Mixed Methods [27], namely: a mixed-method that combines quantitative (closed questions) and qualitative (open questions) approaches to answer research questions [28]. The subjects in this study were 147 Muslim patients who received inpatient services at the Banjarmasin Islamic Hospital. The research subjects were obtained through consecutive sampling techniques with the following criteria: patients who have good consciousness, are treated for at least three days, receive services from the hospital $3 \times 24$ hours, and are willing to be respondents. The independent variable in this study is the integrity of Islamic interpersonal competence (aspects that reflect it consist of Al-Luthfu, Al-Adab, Al-'Uthfu, and As-Shabru). At the same time, the dependent variable is healing motivation.

The data collection method for the first stage (quantitative) used a Likert model scale with four answer options (strongly agree, agree, disagree, strongly agree) and two types of statements (favourable and unfavourable). The research scale consists of the Islamic Health Service Scale (a total of 23 items with a reliability coefficient of 0.973 ) and the Healing Motivation Scale (a total of 20 items with a reliability coefficient of 0.964). The rating on the favourite items starts from four to one, while the assessment on the unfavourable item starts from one to four. The data obtained were then analyzed by Chi-Square (to find out the partial relationship of each aspect of the integrity of Islamic interpersonal competence with healing motivation) and Logistic Regression (to determine the effect of the integrity aspect of Islamic interpersonal competence on the healing motivation simultaneously) with a significance value rule of $<0.05$. Second stage (qualitative) phase, data were obtained through interviews and observations during the therapeutic education process (covering the pre-interaction phase, orientation phase, work phase, termination phase) using an inquiry interview and an observation guide consisting of a secondary data checklist form and a process record form of patient therapeutic education. The data were then analyzed using Taxonomy to determine the motivation of the patient's healing, perception of the integrity of Islamic interpersonal competence in nurses, and the obstacles during the therapeutic education process.

\section{RESULTS AND DISCUSSION}

\subsection{Description of research subject characteristics}

This analysis aims to determine the characteristics of the research subjects consisting of gender, age, and education level. From the analysis results, it is known that as many as $52.4 \%$ of Muslim patients are male, and 47,6\% of Muslim patients are female. Based on age characteristics, the average age of Muslim patients receiving inpatient services at Islamic Hospital (RSI) Banjarmasin is 21-40 years (early adulthood). Meanwhile, based on education, most Muslim patients had high school education. The results of the descriptive analysis are pesented in Table 1. 
Table 1. Distribution of characteristics of inpatient muslim patients

\begin{tabular}{lcc}
\hline \multicolumn{1}{c}{ Characteristics } & f & $\%$ \\
\hline Gender & 77 & $52.4 \%$ \\
Men & 70 & $47.6 \%$ \\
$\quad$ Women & & \\
Age (years old) & 2 & $1.4 \%$ \\
$\quad$ Advanced adulthood (61<) & 38 & $25.9 \%$ \\
$\quad$ Middle adulthood (41-60) & 94 & $63.9 \%$ \\
Early adulthood (21-40) & 10 & $6.8 \%$ \\
Late teens (17-20) & 3 & $2 \%$ \\
Early teens (16>) & & \\
Level of education & 21 & $14.3 \%$ \\
$\quad$ Primary school & 35 & $23.8 \%$ \\
Junior high scool & 55 & $37.4 \%$ \\
$\quad$ Senior high school & 36 & $24.5 \%$ \\
$\quad$ College & & \\
\hline
\end{tabular}

\subsection{Description of the distribution of healing motivation in patients}

This analysis aims to determine the frequency distribution of healing motivation in Muslim patients who receive inpatient services at RSI Banjarmasin. From the analysis results, it is known that as many as $59.2 \%$ of Muslim patients have high healing motivation, and $40.8 \%$ of Muslim patients have low healing motivation. Some of the patient's answers that reflect the low motivation for healing are: i) How is it possible to perform prayers while sick, even with the help of other people and nurses; ii) How is it possible to think about health when you are sick; iii) Support and advice from nurses do not make health better; iv) When you are sick, all you can do is surrender and wait to die.

\subsection{Description of Islamic interpersonal competence integrity in nurses}

This descriptive analysis aims to determine the percentage of Muslim patients' assessments of the integrity of Islamic interpersonal competencies possessed by inpatient nurses at RSI Banjarmasin. The analysis results show that as many as $41.5 \%$ of Muslim patients have a good assessment, and $58.5 \%$ of Muslim patients have a lousy assessment. While the assessment based on aspect shows that as many as $57.8 \%$ of Muslim patients have a good assessment, and 42.2\% of Muslim patients have a lousy assessment of Al-Luthfu owned by nurses. Some of the patient's answers that reflect the low level of Al-Luthfu on nurses include; patients think that nurses do not provide explanations about the rights and obligations of patients, patients also feel tense when interacting with nurses, and some nurses have an attitude of not caring about the patient's condition. In the aspect of $A l-A d a b$, it is known that as many as $50.3 \%$ of Muslim patients have sound judgments and $49.7 \%$ of Muslim patients have a lousy assessment. Several things experienced by patients related to the low assessment of this aspect include feeling offended by being cornered by nurses, and some nurses do not uphold patients' rights. In the aspect of Al-'Uthfu, the percentage of Muslim patients who have a good assessment is $60.5 \%$, and $39.5 \%$ of Muslim patients have a lousy assessment. Patients who have a low assessment of this aspect assume that the time given by nurses in providing information and education is minimal. Besides that, some nurses also do not respond to questions from patients. In the aspect of As-Shabru, it is known that as many as $59.2 \%$ of Muslim patients have sound judgments and $40.8 \%$ of Muslim patients have a lousy assessment. Some patients who have a lousy assessment assume nurses did not have the patience to provide education so that the patient did not fully understand the information provided.

\subsection{Bivariate analysis}

This bivariate analysis (Chi-square) aims to determine the partial relationship between Al-Luthfu, $A l$-Adab, Al-'Uffu, and As-Shabru with healing motivation. The analysis results showed a significant relationship between every aspect of the integrity of Islamic interpersonal competence with healing motivation. The values obtained for each aspect are $\mathrm{p}<0.05$ (the analysis results can be seen in Table 2). These four aspects were then selected bivariate using Logistic Regression.

Table 2. Results of bivariate analysis with Chi-square

\begin{tabular}{cccc}
\hline Aspects of akhlaqul karimah & Chi square & p-value & Information \\
\hline Al-Luthfu & 7.753 & .005 & Related \\
Al-Adab & 18.181 & .000 & Related \\
Al-'Uthfu & 22.537 & .000 & Related \\
As-Shabru & 61.724 & .000 & Related \\
\hline
\end{tabular}

Int J Public Health Sci, Vol. 11, No. 1, March 2022: 359-368 


\subsection{Bivariate selection}

Bivariate selection analysis in this study aims to determine what aspects are eligible to enter multivariate modelling. The rule used refers to a p-value $<0.25$ [29]. The results show that all aspects of the integrity of Islamic interpersonal competence are eligible to enter the multivariate modelling (having a p-value <0.25); thus, all aspects can be included in the multivariate analysis. The results of the bivariate selection are presented in Table 3 .

Table 3. Bivariate selection results using Logistic Regression

\begin{tabular}{ccccccc}
\hline Aspects of akhlaqul karimah & B & SE & Wald & df & $p$ & Exp \\
\hline Al-Luthfu & 1.014 & .347 & 8.523 & 1 & .004 & 2.755 \\
Al-Adab & 1.570 & .365 & 18.535 & 1 & .000 & 4.806 \\
Al-'Uthfu & 1.756 & .370 & 22.545 & 1 & .000 & 5.786 \\
As-Shabru & 3.219 & .448 & 51.591 & 1 & .000 & 25 \\
\hline
\end{tabular}

\subsection{Multivariate analysis}

The multivariate analysis in this study aims to determine the effect of Al-Luthfu, Al-Adab, Al-'Uffu, and As-Shabru simultaneously on healing motivation. From the second stage of multivariate modelling analysis results, only aspects of Al-Luthfu, Al-'Uffu, and As-Shabru were eligible to be included in the Omnibus Test (having a p-value $<0.25$ ). The results of the analysis are shown in Table 4.

Table 4. Multivariate Modeling Analysis Results

\begin{tabular}{ccccccc}
\hline Aspects of Akhlaqul Karimah & B & SE & Wald & df & $p$ & Exp \\
\hline Al-Luthfu & 1.457 & .554 & 6.908 & 1 & .009 & 4.292 \\
Al-'Uthfu & 1.169 & .492 & 5.638 & 1 & .018 & 3.219 \\
As-Shabru & 3.434 & .546 & 39.507 & 1 & .000 & 30.986 \\
\hline
\end{tabular}

The results of the Omnibus Test on this coefficient model produce an $\mathrm{x}^{2}$ value of 86.984 with a significance of 0.000 ( $\mathrm{p}$-value $<0.25$ ), so this regression model can be used to predict healing motivation. Thus, it can be said that simultaneously there is a very significant influence of aspects of Al-Luthfu, Al-'Uffu, and As-Shabru on the motivation of healing. Furthermore, to determine how much contribution these three aspects make to the healing motivation, the Nagelkerke R Square test can be done.

\subsection{Nagelkerke $R$ square test}

From the Nagelkerke R square analysis results, a value of 0.602 was obtained; This means that the contribution of the three aspects of the integrity of Islamic interpersonal competence to the healing motivation is $60.2 \%$. At the same time, the remaining $39.8 \%$ is influenced by factors outside the research variables, such as family support, hospital services, and hospital environment [30]. The results of the analysis ar presented in Table 5 .

Table 5. Nagelkerke R square test results

\begin{tabular}{cccc}
\hline Step & -2 Log Likelihood & Cox and Snell R square & Nagelkerke R square \\
\hline 1 & 111.814 & .447 & .602 \\
\hline
\end{tabular}

\subsection{Exposure to the implementation of therapeutic education in patients}

The results of the taxonomic analysis of the implementation of the therapeutic education process in patients based on the pre-interaction phase, orientation phase, work phase, and termination phase are presented in Table 6 (see Appendix).

\section{DISCUSSION}

The results of this study indicate that the As-Shabru aspect occupies the highest position in influencing healing motivation. Then, "Why does the patience of nurses greatly affect the motivation of healing in patients?". To answer this question, the researcher makes an underlying reason. 


\subsection{Patience as a foundation of service}

According to the researcher, serving as a health worker (nurse) in a hospital is a loyalty to a noble task. Consistency in applying knowledge and expertise in various matters comes and goes, even with expectations that sometimes do not match expectations, such as providing health services wholeheartedly according to hospital demands, even in conditions of work fatigue. Therefore obedience in serving patients requires sacrifice and patience. In this condition, the maturity of speaking and behaving nurses will grow wise.

There are three dimensions in nurses who have patience. The first dimension is social; Serving patients is a social task. In the dynamics of social life, nurses do not escape trials that require patience. Islam recommends that everyone invites to the patient [31]. In the same context Q.S. Al-Balad/90:17 [32] is also to place truth and patience as objects that must be socialized. Thus, whatever is experienced by nurses and patients, they should be able to both maintain patience, not lose hope and strengthen each other in the treatment process [33]. The second dimension is moral; Islam teaches that nurses should be oriented to human benefit and uphold human dignity [34]. In this case, nurses are always required to be aware that what they do can be helpful for others and themselves [35]. The third dimension is intelligence; nurses' patience is the result of contemplation of the perfection of the mind. On this basis, the patience of nurses reflects their intelligence [36]. The principal value of patience lies in the awareness of the source of the highest value that must be a reference in acting and thinking, namely the holy book of the Qur'an. Therefore, Islam describes patience in Q.S. Ar-Ruum/30:28 [37] is equivalent to Qaumun Ya'qilun (people who like to think and contemplate) and the Ulil Albab scholar group (people who have common sense). Nurses who have these three dimensions of patience will show a rational ability that plays a more critical role in controlling lust and emotions. Thus, it can be understood that patience is the basic foundation of devotion. As stated in Q.S. AlMuddastir/74:17 [38], that "Why is the command to carry out the apostolic task in Islam accompanied by instructions to be patient? The answer is so that humans can successfully carry out this apostolic task." Therefore, when nurses are willing to be patient to devote themselves to serving patients even though it is difficult, patients will appreciate it by being willing to obey, respect, trust and realize the importance of advice from nurses.

\subsection{Patience as a self defense system}

According to researchers, nurses' patience is a self-defence system that is oriented to emotional control. This system relieves emotions generated by stressors, such as unpleasant behaviour or speech from the patient [39]. There are two forms of the self-defence system. The first is minimization, the Effort to deny the existence of a problem. Nurses with minimization when facing problems will judge that something that bothers them is not a problem [40]. The second is the search for meaning, efforts to take lessons from an unpleasant incident. Nurses who search for meaning when facing problems will see things from a positive perspective (what lessons can be learned) [41]. Islam teaches in Q.S. Al-Baqarah/2:269 [42] that Muslims are obliged to take lessons that occur or are hidden behind an incident. Therefore, nurses with a robust selfdefence system will withstand the hardships of serving and taking on the responsibility of serving patients, such as limited time with family, vacation time, social contact with the broader community, and other matters relating to the patient.

\subsection{Patience as sincerity}

According to the researcher, the growth of patience in nurses is due to the goals to be achieved. Q.S. Az-Zariyat/51:56 [43] explained that the primary goal of humans in this life is to obey and submit to Allah. When implemented in health services, a nurse must sincerely serve patients to expect Allah's pleasure. A nurse who does not have the sincerity of heart will serve the patient with compulsion so that the burden of duty and suffering feels heavy [44]. Conversely, nurses who have sincerity will serve patients with feelings of pleasure so that their workload feels light [45].

For this reason, it is necessary to straighten the purpose of life because Islam guarantees a victory for people who have patience (sincere hearts in carrying out their duties), as Allah says in Q.S. Al-Anfaal/8:65 [46] that "if there were a hundred of you who were patient, they would surely be able to defeat two hundred of the disbelievers; And if there were a thousand among you who were patient, they would surely be able to defeat two thousand with Allah's permission." Based on this verse, the researcher is increasingly convinced by the results of this study that nurses' patience influences the motivation of patient recovery.

\section{CONCLUSION}

From the results of this study, several points can be concluded. On average, inpatients at RSI Banjarmasin have high healing motivation. On average, inpatients at RSI Banjarmasin have a lousy perception of the integrity of the Islamic interpersonal competence of nurses. Partially, the aspects of $A l$ - 
Luthfu, Al-Adab, Al-'Uthfu, and As-Shabru are related to the motivation for healing inpatients at RSI Banjarmasin. Barriers experienced by nurses during the therapeutic education process for patients are: nurses are not ready to provide education, the information provided between nurses and other nurses is inconsistent, there is no priority to provide education, and the limited time nurses have in providing education. While the obstacles experienced by patients are: stress due to coronary disease, less representative environment, limited time due to early discharge, undirected educational targets, and lack of support from nurses.

\section{ACKNOWLEDGEMENTS}

The authors would like to thank the Antasari State Islamic University of Banjarmasin, Samarinda State Islamic Institute, and the Banjarmasin Islamic Hospital for technical assistance in this research. The authors also thank all health care workers and inpatients for their efforts to participate and assist in this study.

\section{REFERENCES}

[1] R. Arena et al., "Applying precision medicine to healthy living for the prevention and treatment of cardiovascular disease,"Current Problems in Cardiology, vol. 43, no. 12, pp. 448-483, 2018, doi: 10.1016/j.cpcardiol.2018.06.001.

[2] A. T. Sawyer, S. L. Harris, and H. G. Koenig, "Illness perception and high readmission health outcomes," Health Psychology Open, vol. 6, no. 1, pp. 1-11, 2019, doi: 10.1177/2055102919844504.

[3] B. Murti, Epidemiological Research Principles and Methods (In Indonesia: Prinsip dan Metode Riset Epidemiologi). Surakarta: Universitas Sebelas Maret, 2016.

[4] K. S. Gupta and V. Rokade, "Importance of quality in health care sector: A review," Journal of Health Management, vol. 18, no. 1, pp. 84-94, 2016, doi: 10.1177/0972063415625527.

[5] I. Corrin, "A service evaluation to examine the experience of patients attending wound healing outpatient clinics in South Wales," Br J Community Nurs, vol. 23, no. 6, pp. 6-12, 2018, doi: 10.12968/bjen.2018.23.Sup6.S6

[6] B. Mehraki and A. Gholami, "Physical and mental health in Islam", ME-JFM, vol. 15, no. 9, pp. 142-148, 2017, doi: 10.5742/MEWFM.2017.93114.

[7] G. A. Tzeferakos and A. I. Douzenis, "Islam, mental health and law: A general overview", Ann Gen Psychiatry, vol. 16, no. 28, pp. 1-6, 2017, doi: 10.1186/s12991-017-0150-6.

[8] Q. Shihab, Tafsir Al-Misbah: Message, Impression and Harmony of the Qur'an (In Indonesia: Tafsir Al-Misbah: Pesan, Kesan dan Keserasian Al-Our'an). Jakarta: Lentera Hati, 2012.

[9] Q. Shihab, Membumikan Al-Qur'an: Fungsi dan peran wahyu dalam kehidupan masyarakat. Bandung: Mizan, 2014.

[10] K. Turney and C. Wildeman, "Mental and physical health of children in foster care," Pediatrics, vol. 138, no. 5, pp. 1-13, 2016, doi: 10.1542/peds.2016-1118

[11] E. K. Adam, M. E. Quinn, R. Tavernier, M. T. McQuillan, K. A. Dahlke, and K. E. Gilbert, "Diurnal cortisol slopes and mental and physical health outcomes: A systematic review and meta-analysis," Psychoneuroendocrinology, vol. 83, pp. 25-41, 2017, doi: 10.1016/j.psyneuen.2017.05.018

[12] H. I. Kaplan and B. J. Sadock, Synopsis of Psychiatry: Behavioral Sciences/Clinical Psychiatry. Philadelphia: Lippincott Williams \& Wilkins, 2014

[13] M. W. Otto and J. A. J. Smits, "Anxiety sensitivity, health behaviors, and the prevention and treatment of medical illness," Clinical Psychology: Science and Practice, vol. 25, no. 3, pp. 1-3, 2018, doi: 10.1111/cpsp.12253.

[14] H.-J. Kang et al., "Impact of anxiety and depression on physical health condition and disability in an elderly Korean population," Psychiatry Investig, vol. 14, no. 3, pp. 240-248, 2017, doi: 10.4306/pi.2017.14.3.240.

[15] C. Charalambous et al., "The Impact of stress on pressure ulcer wound healing process and on the psychophysiological environment of the individual suffering from them," Med Arch, vol. 72, no. 5, pp. 362-366, 2018, doi: 10.5455/medarh.2018.72.362-366

[16] R. Hardhiyani, "Nurse therapeutic communication relationship with motivation to recover in hospitalized patients (In Indonesia: Hubungan komunikasi therapeutic perawat dengan motivasi sembuh pada pasien rawat inap)," Developmental and Clinical Psychology, vol. 2, no. 2, pp. 56-61, 2013.

[17] T. J. Nielsen, M. Vestergaard, B. Christensen, K. S. Christensen, and K. K. Larsen, "Mental health status and risk of new cardiovascular events or death in patients with myocardial infarction: A population-based cohort study," BMJ Open, vol. 3, no. 8, pp. 1-10, 2013, doi: 10.1136/bmjopen-2013-003045.

[18] B. Lumenta, Hospital: Image, Role and Function (In Indonesia: Hospital: Citra, Peran dan Fungsi). Yogyakarta: Kanisius, 2016.

[19] P. W. Iyer and N. H. Camp, Nursing Documentation: A Nursing Process Approach. Jakarta: EGC, 2015.

[20] S. Ahmed, K. Md. Tarique, and I. Arif, "Service quality, patient satisfaction and loyalty in the Bangladesh healthcare sector', IJHCQA, vol. 30, no. 5, pp. 477-488, 2017, doi: 10.1108/IJHCQA-01-2017-0004.

[21] T. Fatima, S. A. Malik, and A. Shabbir, "Hospital healthcare service quality, patient satisfaction and loyalty: An investigation in context of private healthcare systems," IJQRM, vol. 35, no. 6, pp. 1195-1214, 2018, doi: 10.1108/IJQRM-02-2017-0031.

[22] B. Takwin, "Understanding the self-esteem and self-integrity of Indonesians (In Indonesia: Memahami pemanaan diri dan integritas diri orang Indonesia)," Jurnal Ilmiah Psikologi, pp. 1-17, 2013.

[23] I. Miskawaih, Tahdib Al-Akhlaq. Bandung: Mizan, 1996.

[24] Kemenkes Republik Indonesia, Hospital Accreditation Standard (In Indonesia: Standar Akreditasi Rumah Sakit). Jakarta: Dirjen Bina Pelayanan Medik Depkes RI, 2011.

[25] G. W. Stuart, Principles and Practice of Psychiatric Nursing. Missouri: Mosby, 2011.

[26] J. B. Riley, Communication in Nursing. Amsterdam: Elsevier, 2019

[27] J. M. Morse, Mixed Method Design: Principles and Procedures. London: Routledge, 2018.

[28] J. W. Creswell and V. L. P. Clark, Designing and Conducting Mixed Methods Research. California: SAGE, 2017.

[29] B. Lapau, Health Research methods: The Scientific Method of Writing Thesis, Thesis, and Dissertation (In Indonesia: Metode Penelitian Kesehatan: Metode Ilmiah Penulisan Skripsi, Tesis, dan Disertasi), Jakarta: Yayasan Pustaka Obor Indonesia, 2013.

[30] R. Lloyd, Quality Health Care: A Guide to Developing and Using Indicators. Massachusetts: Jones \& Bartlett Learning, 2017.

[31] Al-Qur'an, Surat Al-Ashr Ayat 3. 
[32] Al-Qur'an, Surat Al-Balad Ayat 17.

[33] N. Roitenberg, "Managing (im) patience of nurses and nurse's aides: Emotional labour and normalizing practices at geriatric facilities," Sociol Health Illn, vol. 43, no. 4, pp. 995-1011, 2021, doi: 10.1111/1467-9566.13281.

[34] Al-Qur'an, Surat Al-Muddatstsir Ayat 7.

[35] I. Kouatly, M. Nizam, T. Arawi, and L. K. Badr, "Moral and professional values of nurses in Lebanon," The Journal of Continuing Education in Nursing, vol. 52, no. 9, pp. 429-437, 2021, doi: 10.3928/00220124-20210804-09.

[36] C. Başoğul and G. Özgür, "Role of Emotional Intelligence in Conflict Management Strategies of Nurses," Asian Nursing Research, vol. 10, no. 3, pp. 228-233, 2016, doi: 10.1016/j.anr.2016.07.002.

[37] Al-Qur'an, Surat Ar-Ruum Ayat 28.

[38] Al-Qur'an, Surat Al-Muddastir Ayat 17.

[39] S. Birnbaum, "Confronting the social determinants of health: Has the language of trauma informed care become a defense mechanism?," Issues in Mental Health Nursing, vol. 40, no. 6, pp. 476-481, 2019, doi: 10.1080/01612840.2018.1563256.

[40] F. Elyasi et al., "The relationship between defense mechanisms and nurses' occupational burnout: A cross-sectional study," Iran $J$ Psychiatry Behav Sci, vol. 14, no. 4, pp. 1-12, 2020, doi: 10.5812/ijpbs.106716.

[41] R. C. N. P. Rocha, E. R. Pereira, R. M. C. R. A. Silva, A. Y. B. B. V. de Medeiros, and A. M. da F. Marins, "The meaning of life of nurses working in palliative care: Integrative literature review," Rev. Eletr. Enf., vol. 22, pp. 1-12, 2020, doi: 10.5216/ree.v22.56169.

[42] Al-Qur'an, Surat Al-Baqarah Ayat 269.

[43] Al-Qur'an, Surat Az-Zariyat Ayat 56

[44] M. A. Bhatti, M. S. Hussain, and M. A. Al Doghan, "The role of personal and job resources in boosting nurses' work engagement and performance," Global Business and Organizational Excellence, vol. 37, no. 2, pp. 32-40, 2018, doi: 10.1002/joe.21840.

[45] E. Alomeroglu, S. Guney, M. Sundu, O. Yasar, and S. Akyurek, "The Relationship between Five Factor Personalities and Alienation to Work of Nurses in Teaching and Research Hospitals," Eurasia J Math Sci T, vol. 14, no. 1, pp. 117-122, 2018, doi: 10.12973/ejmste/77168.

[46] Al-Qur'an, Surat Al-Anfaal Ayat 65.

\section{BIOGRAPHIES OF AUTHORS}
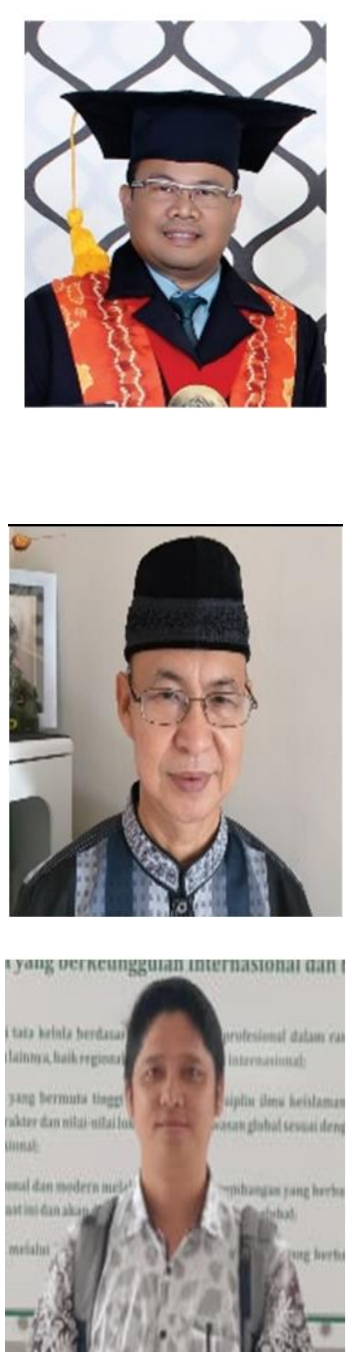

Taufik Hidayat (D) SD SC P is a lecturer in Islamic Counseling Guidance at the Faculty of Da'wah and Communication Studies, Antasari State Islamic University. He obtained a Psychology Profession degree from Wisnuwardhana University, a degree M.Kes. from Diponegoro University, and a degree Dr. from Antasari State Islamic University. Before becoming a lecturer, he served as a Psychologist at the Brigjend Regional General Hospital. $\mathrm{H}$. Hasan Basry Kandangan. In addition, he is also active in various organizations outside the academic field, among others as a member of the Indonesian Psychological Association for Inter-Institutional Relations in the South Kalimantan Region, a member of the Indonesian Forensic Psychology Association in the South Kalimantan Region, a member of the Darul Ulum Kandangan Education Foundation, and Deputy Chair of the Clinical Psychology Association Indonesia South Kalimantan Region. His research focus is Public Health Sciences and Islamic Studies. $\mathrm{He}$ can be contacted via email: t_140581@yahoo.co.id.

Mahyuddin Barni (D) Id SC P is a Professor of Islamic Religious Education at Antasari State Islamic University. He received a degree M.Ag. from Alauddin State Islamic University and a degree Dr. from Syarif Hidayatullah State Islamic University. He has held several positions at Antasari State Islamic University, namely: Secretary of the Arabic Language Education Study Program, Faculty of Tarbiyah, Assistant Dean III of the Faculty of Tarbiyah for Student Affairs, Assistant to Vice-Chancellor III for Student Affairs and Cooperation, and Director of Postgraduate. His research focus is on Islamic Religious Education. He can be contacted via email: mahyuddinbarni@yahoo.co.id.

Agus Setiawan (D) 8d SC P is a lecturer in Islamic Religious Education at the Faculty of Tarbiyah and Teacher Training, Sultan Aji Muhammad Idris State Islamic University. He received a degree M.Pd.I. from Sultan Aji Muhammad Idris State Islamic University and a degree Dr. from Antasari State Islamic University. He is a Reviewer of the Borneo International Journal of Islamic Studies and a Reviewer of the Islamic Education Journal at the State Islamic University of Sunan Gunung Djati. His research focus is on Islamic Religious Education. He can be contacted via email: agus.setiawan@iain-samarinda.ac.id. 


\section{APPENDIX}

Table 6. Implementation of the therapeutic education process based on the integrity of Islamic interpersonal competence

\begin{tabular}{|c|c|c|c|}
\hline Education phase & Action & Implementation & $\begin{array}{l}\text { Integrity of Islamic } \\
\text { interpersonal } \\
\text { competency }\end{array}$ \\
\hline $\begin{array}{l}\text { Pre-interaction } \\
\text { phase }\end{array}$ & $\begin{array}{l}\text { 1) Collecting data about } \\
\text { patients, 2) Exploring the } \\
\text { patient's feelings, } \\
\text { fantasies, and fears, 3) } \\
\text { Analyzing one's own } \\
\text { professional strengths and } \\
\text { limitations, 4) Making a } \\
\text { meeting plan (activities, } \\
\text { time, place, } \\
\text { material/information) }\end{array}$ & $\begin{array}{l}\text { Self evaluation } \\
\text { 1) Knowledge held about the disease, 2) What will be } \\
\text { said when meeting a patient, 3) What is the response if } \\
\text { the patient is silent, refused, or angry, 4) Make } \\
\text { corrections on ways of interacting with patients, 5) } \\
\text { Manage anxiety levels and overcome them. } \\
\text { Determination of interpersonal stages } \\
\text { 1) Is the first meeting, 2) Have a follow-up meeting, 3) } \\
\text { What is the purpose of the meeting (Assessment/ } \\
\text { observation/monitoring/action/termination). } \\
\text { Education plan } \\
\text { 1) Prepare in writing the plan to be carried out, 2) } \\
\text { Interpersonal techniques to be applied, and related to } \\
\text { treatment goals, 3) What observation techniques are } \\
\text { needed, 4) Procedural steps to be carried out (SOP). }\end{array}$ & Al-Luthfu, As-Shabru \\
\hline $\begin{array}{l}\text { Orientation } \\
\text { phase }\end{array}$ & $\begin{array}{l}\text { 1) Greet and smile to the } \\
\text { patient, 2) Introduce } \\
\text { yourself and ask the } \\
\text { patient's name, 3) Perform } \\
\text { validation (cognitive, } \\
\text { psychomotor, affective) at } \\
\text { the next meeting, 4) } \\
\text { Determine why patients } \\
\text { seek help, 5) Provides } \\
\text { trust, acceptance and } \\
\text { interpersonal } \\
\text { relationships, 6) Make a } \\
\text { reciprocal contract, 7) } \\
\text { Explore the feelings, } \\
\text { thoughts and actions of the } \\
\text { patient, 8) Identify patient } \\
\text { problems, 9) Explain the } \\
\text { time needed to carry out } \\
\text { treatment, 10) Explain the } \\
\text { conditions } \\
\text { information needed to } \\
\text { make treatment decisions, } \\
\text { 11) Explain and confirm } \\
\text { the confidentiality of } \\
\text { information. }\end{array}$ & $\begin{array}{l}\text { Greeting } \\
\text { Assalamualaikum/goodmorning/afternoon/evening/night } \\
\text { or according to socio-cultural background accompanied } \\
\text { by reaching out to shake hands. } \\
\text { Introduce myself } \\
\text { 1) "My name is ... I'm happy to be called ...", 2) Ask the } \\
\text { patient's name; "Your name, what is your nickname?". } \\
\text { Agree on a meeting (contract) } \\
\text { 1) "How about we talk?"; 2) "Let's talk"; 3)"Let's sit } \\
\text { there," if in the patient's room, immediately sit next to } \\
\text { the patient. } \\
\text { Facing contracts (trust) } \\
\text { 1) "I am an officer working in ..., I will take care of you } \\
\text { for } 3 \text { days. Starting now ... I come at 07.00 and go home } \\
\text { at } 14.00 ", 2 \text { ) "I will help to cure your illness", 3) "We } \\
\text { will learn together and be enthusiastic". } \\
\quad \text { Start the initial conversation } \\
\text { 1) "What happened at home to being taken to the } \\
\text { hospital?", 2) "What's troubling right now?", 3) "What } \\
\text { complaints do you feel?" } \\
\quad \text { Ending introductions } \\
\text { "Our introduction is sufficient and happy to help" }\end{array}$ & $\begin{array}{l}\text { Al-Luthfu } \\
\text { Al-Adab } \\
\text { Al-'Uthfu } \\
\text { As-Shabru }\end{array}$ \\
\hline Work phase & $\begin{array}{l}\text { 1) Give the patient a } \\
\text { chance to ask, 2) Asking } \\
\text { the main complaints/ } \\
\text { complaints that may be } \\
\text { related to the smooth } \\
\text { implementation of } \\
\text { activities, 3) Start the } \\
\text { activity in a good way, 4) } \\
\text { Carry out activities } \\
\text { according to plan. }\end{array}$ & $\begin{array}{l}\text { 1) Improve the understanding and recognition of } \\
\text { patients about themselves, their behavior, feelings, } \\
\text { thoughts (cognitive). - "What causes anxiety?" - "What } \\
\text { are the signs/symptoms that you feel when you are } \\
\text { worried?" - "Whenever you feel anxious?" } \\
\text { 2) Develop, maintain and improve the ability of patients } \\
\text { to independently solve the problems at hand (affective } \\
\text { and psychomotor). - "What do you do when you're } \\
\text { worried?" - "What do you do when your heart beats?" - } \\
\text { "Is that how your problem is solved?" - "Is that way the } \\
\text { heart palpitations are gone?" - "What could be a better } \\
\text { way?" - "How about we talk about some new ways?" } \\
\text { Tell! - "Which method do you want to try?" "I will give } \\
\text { an example (demonstration)," "Try to copy the method } \\
\text { earlier?" - How about trying it yourself?" } \\
\text { 3) Carry out therapy - "How is your pain?" - "I help you } \\
\text { try to reduce pain." - "First: turn your mind to a pleasant } \\
\text { experience, or read the Koran, listen to recitations, or } \\
\text { dhikr," - "Second: breathing exercises" (give an } \\
\text { example) - "Third: stroking certain areas" (give an } \\
\text { example) - "Let's try it" (Help patients do it, give praise } \\
\text { if you can do). - "How do you feel?" - Well, you can try } \\
\text { it in pain, but if it doesn't work, call the officer" } \\
\text { 4) Carry out health education. - "In accordance with our } \\
\text { promise, I will provide an explanation of how to care for } \\
\text { the umbilical cord newborn" - Explain with flipcharts }\end{array}$ & $\begin{array}{l}\text { Al-Luthfu } \\
\text { Al-Adab } \\
\text { Al-'Uthfu } \\
\text { As-Shabru }\end{array}$ \\
\hline
\end{tabular}




\begin{tabular}{|c|c|c|c|}
\hline Education phase & Action & Implementation & $\begin{array}{c}\text { Integrity of Islamic } \\
\text { interpersonal } \\
\text { competency }\end{array}$ \\
\hline $\begin{array}{c}\text { Termination } \\
\text { phase }\end{array}$ & $\begin{array}{l}\text { 1) Creating separation, 2) } \\
\text { Summing up the results of } \\
\text { activities; Evaluate the } \\
\text { results of the educative } \\
\text { process, 3) Expose each } \\
\text { other feelings of rejection, } \\
\text { loss, sadness, anger, and } \\
\text { other behaviors, 4) } \\
\text { Providing functionalistic } \\
\text { learning methods with } \\
\text { positive reinforcement, 5) } \\
\text { Plan a follow up with the } \\
\text { patient, 6) Enter a contract } \\
\text { for the next meeting (time, } \\
\text { place, topic), 7) End the } \\
\text { activities well. }\end{array}$ & $\begin{array}{l}\text { /booklets /booklets. - "Any question? Is something } \\
\text { unclear? " - "You and your family may try to do it at } \\
\text { home. Thank you" } \\
\text { 5) Carry out collaboration. - "Brother, it's } 12.00 \text { o'clock, } \\
\text { it's time to get an injection" - "Brother, tilt to the left" - } \\
\text { "A little sick (say when going to inject), take a deep } \\
\text { breath," Bismillahirrahmanirrahim," "already" } \\
\text { 6) Carry out observation and monitoring. - "Brother, } \\
\text { according to the state of your high temperature so every } \\
\text { two hours I will measure your temperature, pulse and } \\
\text { respiration" } \\
\text { Conduct temporary terminations; Fill in the } \\
\text { conversation } \\
\text { 1) Evaluation of results; "Please state the things we've } \\
\text { talked about", "What have you got from this } \\
\text { conversation?", 2) follow up; "What if you try to do it } \\
\text { later in the room?", "Which one do you want to try?", 3) } \\
\text { Upcoming contracts, Time; "When do we meet again?", } \\
\text { "What if later ... we meet again?", "We will meet again } \\
\text { tomorrow morning", Topic; "What will we talk about } \\
\text { later/tomorrow", "What if we learn ..." (mention) } \\
\text { Conduct final termination } \\
\text { 1) Evaluation of results; "Try to mention the ability } \\
\text { gained after being treated here?", "What have you } \\
\text { known while being treated here?", "I see you can do" } \\
\text { (Mention according to the results of observations on } \\
\text { each action), 2) Follow up; "What are your planned } \\
\text { activities at home?", "What are the symptoms and signs } \\
\text { that need attention at home?", 3) Future contracts; If you } \\
\text { experience the same complaint just contact us } \\
\text { immediately or return to the hospital " }\end{array}$ & $\begin{array}{l}\text { Al-Luthfu } \\
\text { Al-Adab } \\
\text { Al-'Uthfu } \\
\text { As-Shabru }\end{array}$ \\
\hline
\end{tabular}

